\title{
DESIGN OF BRIQUETTING PRESS - FROM IDEA TO START OF PRODUCTION
}

\author{
Arkadiusz Kowalski ${ }^{1}$, Przemyslaw Frankowski ${ }^{1}$, Agnieszka Tychoniuk ${ }^{2}$ \\ ${ }^{1}$ Wroclaw University of Science and Technology, Poland; ${ }^{2}$ Silesian University of Technology, Poland \\ arkadiusz.kowalski@pwr.edu.pl,149687@pwr.student.edu.pl, agnieszka.tychoniuk@polsl.pl
}

\begin{abstract}
In the engineering industry, where the main waste is metal shavings, it can be sent for reprocessing and recovered. It is completely different in the case of organic waste, e.g., sawdust or straw. From the point of view of energy recovery, they can be burned. At this point, the question arises how to realize the idea of obtaining energy from organic waste? Wood chips or sawdust are burning very quickly and are in a loose form, which makes furnace power quite bothersome. In order to extend their burning period and improve the comfort of use, it is possible to use the pressing process. The high degree of compaction of the material means that the combustion takes much longer. Briquetting presses are devices that convert uncomfortable waste into a useful product. The article presents the process of a briquetting press design - from the idea, through the design and technology development, strength calculations and the implementation of a simulation model that verifies production assumptions. The design stage of the project contains a detailed description of the dimension selection of the elements of the main hydraulic cylinder. First, calculations of the basic parts of the actuator were made. The next step was to check the individual parts using FEM. In the case of the actuator, the analysis concerns the pressing process and the return stroke. The technological stage of the project includes the selection of the appropriate technology of machining of each of the seven main elements of the actuator. The simulation phase of the project uses the model of the company's production processes. The analysis showed the necessity of providing additional storage areas in the area of production halls and providing an additional number of operators. At this stage, the assumptions regarding the number of deliveries, the size of the production batch, routes and the choice of means of transport were verified.
\end{abstract}

Keywords: briquetting press, design, technology, simulation, production process.

\section{Introduction}

The great progress of human development in the twentieth century is a result of enormous extraction of fossil fuels (hard coal, lignite, oil and natural gas). The continuous exploitation process may lead to their exhaustion. Both in the period of prosperity and in time of recession the enterprises want to achieve maximum income after deduction of all the costs. In each of these periods the enterprise leads a different policy of processes optimisation [1]. Such a threat prompts large corporations, entrepreneurs and inventors to develop alternative energy sources [2]. They result in wind, hydropower, hydroelectric and solar power plants. Another problem is post-production waste [3]. In the machinery industry, the main waste is metal chip, which can be sent for re-melting (after cleaning of machining fluid) and to recover [4-6]. Completely different is in case of organic waste (sawdust or straw), the only possibility of using it is to further process it (chipboards or fertilisers) or combustion for energy recovery [7-9]. Wood chips or sawdust burn very quickly and are present in loose form, which makes feeding furnaces quite troublesome. In order to extend their combustion period and improve the comfort of use, it is possible to use the pressing process [10;11]. Due to high material density, combustion takes much longer, so the need to power the furnace occurs rarely. Therefore, briquetting presses are devices that convert uncomfortable waste into a useful product for power plants or households. Furniture manufacturers or farmers, after purchasing the briquetting press, have a chance to have an additional source of income.

The answer to this market demand is an idea for a riquetting press. This device will achieve high efficiency thanks to its unique drive solution. It is a high-frequency hydraulic cylinder that acts with high force on the load material. Such performance characteristics require careful analysis and testing for strength. In order to obtain the most efficient and economical machine in production and operation, it is necessary to design components with the best possible strength to dimension ratio and the highest degree of technological performance. The aim of the article is to propose a model design process for a hydraulic cylinder (in terms of design, strength and technology), designed to drive the briquetting press that meets specific assumptions and requirements of potential customers and to verify production plans using a simulation model of the cylinder manufacturing system, under conditions typical for small production company. 


\section{Construction of the briquetting press}

The briquetting press due to clear market demand is a machine with the following features (some pointers on the design of briquetting press can be found in the literature $[12 ; 13])$ :

- strong, compact design;

- high productivity;

- low sensibility to batch changes.

The machine was designed using Computer Aided Design (CAD) system and calculated in terms of strength using Finite Element Method (FEM). In order to ensure high reliability and speed, only maintenance-free hydraulic motors have been used. In addition, the device will be equipped with:

- air oil cooler;

- filters with contamination sensors;

- electronic temperature measurement of working liquid;

- electronic liquid level indicator.

The basic assumptions and technological parameters of presses, in two versions, were presented in Table 1.

Table 1

Technical parameters of briquetting presses, in two versions

\begin{tabular}{|c|c|c|}
\hline Parameter name & Version I & Version II \\
\hline Power supply & $400 \mathrm{~V}, 3 \mathrm{PH}, 50 \mathrm{~Hz}$ & $400 \mathrm{~V}, 3 \mathrm{PH}, 50 \mathrm{~Hz}$ \\
\hline Electric motor & $18.5 \mathrm{~kW}$ & $30 \mathrm{~kW}$ \\
\hline Mass & $\sim 2400 \mathrm{~kg}$ & $\sim 2700 \mathrm{~kg}$ \\
\hline $\begin{array}{c}\text { Productivity for straw (fragmentation } \\
10 \div 20 \text { mm, humidity } 8 \%)\end{array}$ & $250 \mathrm{~kg} \cdot \mathrm{h}^{-1}$ & $350 \mathrm{~kg} \cdot \mathrm{h}^{-1}$ \\
\hline Softwood sawdust $(5 \div 15 \mathrm{~mm})$ & $280 \mathrm{~kg} \cdot \mathrm{h}^{-1}$ & $400 \mathrm{~kg} \cdot \mathrm{h}^{-1}$ \\
\hline Hardwood sawdust $(5 \div 20 \mathrm{~mm})$ & $320 \mathrm{~kg} \cdot \mathrm{h}^{-1}$ & $455 \mathrm{~kg} \cdot \mathrm{h}^{-1}$ \\
\hline
\end{tabular}

Briquetting presses in version I and II can produce briquettes from different raw materials, with varying degrees of fragmentation and humidity, at different productivity. The type of raw material and its parameters have a direct impact on the quality of the product and efficiency of the equipment. Cuboidal briquette with dimensions of $120 \times 60 \times 80 \mathrm{~mm}$ is a product of the pressing process. This shape results directly from the applied technical solution, as well as the matrix and stamp dimensions. The operation principle of the briquetting press can be easily explained by a simple machine model consisting of several basic elements, presented in Figure 1.

In order to achieve the required performance parameters, it was necessary to use actuators with two different piston diameters, depending on the variant:

- briquetting press actuator Version I, piston diameter $\varnothing 160 \mathrm{~mm}$;

- briquetting press actuator Version II, piston diameter $\varnothing 180 \mathrm{~mm}$.

The next step was a strength analysis carried out with FEM for the body of the briquetting press. It will concern the possibility of loading the assembly with higher forces and fatigue calculations. The analysed area of the machine is shown in Figure 2.

Conducted strength calculations were related to:

- forces in the piston rod axis, taking into account mechanical losses in the layout. From the press point of view, it is important to achieve the highest possible rate of pressing the batch, the more compact and hardercube, the more stable the combustion process. This means that the more force we apply to the material in pressings chamber, the better product we will get. A hydraulic pump of up to $300 \mathrm{MPa}$ is installed per press as a default;

- cycle time of the press, the shorter the cycle time, the higher the productivity;

- analysis of pressures in the hydraulic cylinder during one operation cycle, the data obtained were very helpful in the later strength calculations of the cylinder. 


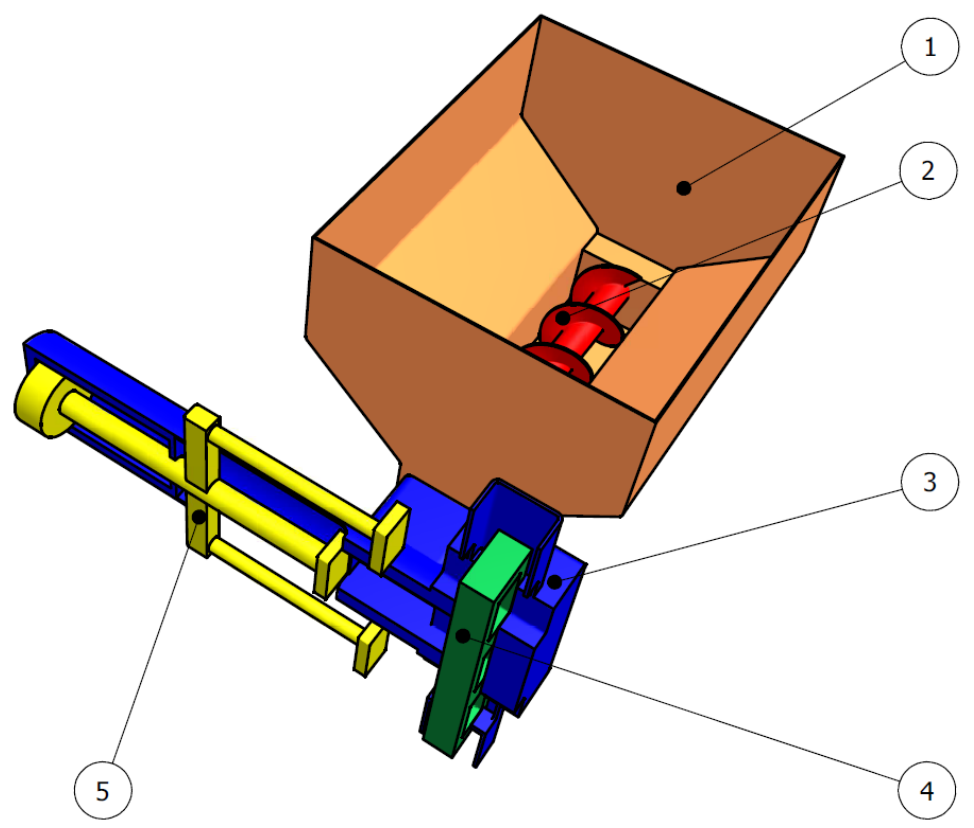

Fig. 1. Components of briquetting press model, where: 1 - hopper; 2 - high-speed worm drive; 3 - body (shown in cross-section), includes pressing chamber, piston body and recess, in which the mould moves; 4 - mould; 5 - piston with seal and ejectors

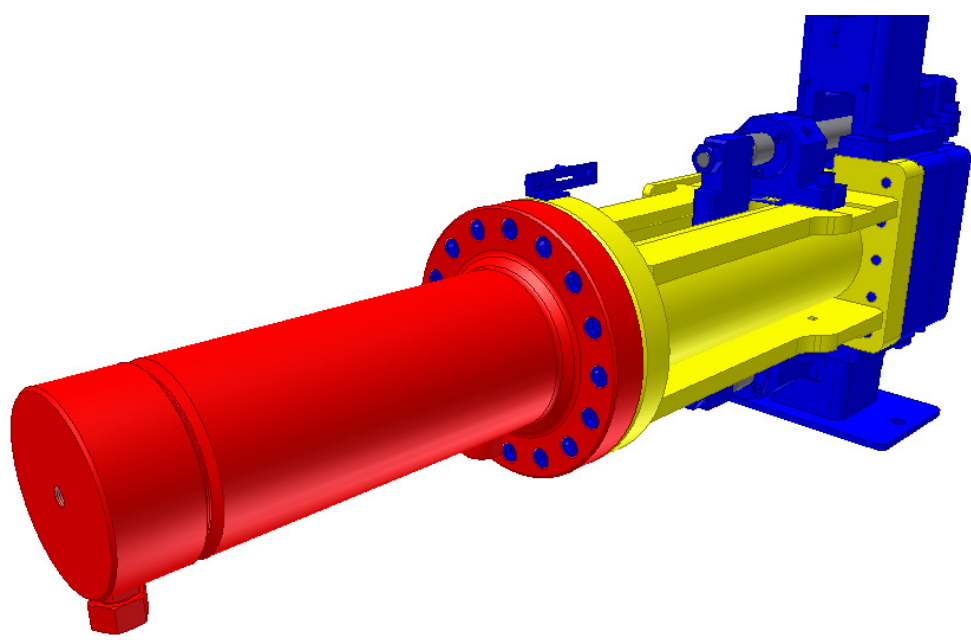

Fig. 2. Layout of analysed components in briquetting press

Another important assumption is material selection based on its strength parameters. It was considered that the material used for construction of the actuator and body will be steel $18 \mathrm{G} 2 \mathrm{~A}$. It is a high-strength alloyed steel with manganese additive, characterised by a small amount of impurities. On the basis of PN-72/M-73202 standard, it was found that the safety factor used for strength calculations should be 1.5 [14]. In addition, it was agreed that the actuator cylinder would be connected to the bottom and flange by means of threaded and welded connection. The gland is to rest in the cylinder, based on the machine body.

\section{Calculation of the cylinder wall}

Cylinders are made of steel (seamless tubes or forgings) and cast iron (castings). The cast iron is more rarely due to possibility of using only to working pressures below $16 \mathrm{MPa}$. Calculations of this element boil down to selection of wall thickness, in literature there are three calculation methods available [15], which in this particular case provided different results:

1. for $\frac{D}{g} \leq 3.2$ the following formula shall be used 


$$
g=\frac{D}{2}\left(\sqrt{\frac{k_{r}+p(1-2 v)}{k_{r}-p(1+v)}}-1\right),
$$

where $D$-internal diameter of the cylinder, $\mathrm{mm}$;

$g$ - cylinder wall thickness, $\mathrm{mm}$;

$k_{r}$ - permissible stresses, $\mathrm{kG} \cdot \mathrm{cm}^{-2}$;

$p$ - maximum pressure inside the cylinder, $\mathrm{kG} \cdot \mathrm{cm}^{-2}$;

$v$ - Poisson's ratio, for steels $v=0.3$;

2. for $3.2 \leq \frac{D}{g}<16$ shall apply

$$
g=\frac{p D}{\left(2.3 k_{r}+p\right) z}+C
$$

where $z$-computational strength rate (for discontinuities, as holes or welded joints, it is 1);

$C$ - corrosion allowance, $\mathrm{mm}$;

3. for $\frac{D}{g} \geq 16$ shall apply:

$$
g=\frac{p n D}{2 k_{r}}
$$

where $n$-safety factor.

In order to verify calculations, FEM calculations were used. Analysing the results, it was considered that cylinders with the internal diameter of $160 \mathrm{~mm}$ and $180 \mathrm{~mm}$ and the wall thicknesses of $9 \mathrm{~mm}$ and $10 \mathrm{~mm}$ would not withstand the specified load and would certainly undergo plastic deformation. The use of a wall of $15 \mathrm{~mm}$ and $17 \mathrm{~mm}$ provides very satisfactory results, as there is a certain "supply", which can significantly prolong its service life in case of momentary pressure drop above the nominal level. The maximum stress does not exceed the yield strength and a safety factor of 1.5 is applied. In terms of the customer's expectations - the product is supposed to work forever - a thicker wall should always be used.

\section{Calculation of the cylinder bottom}

Another important element is the cylinder bottom. It can be calculated using the formula [15]:

$$
h=0.433 d \sqrt{\frac{p}{k_{r}}},
$$

where $d$-internal diameter of the bottom, $\mathrm{cm}$;

$h$ - bottom thickness, $\mathrm{cm}$;

$p$ - working medium pressure, $\mathrm{kg} \cdot \mathrm{cm}^{-2}$;

$k_{r}$ - permissible stresses for cylinder bottom, $\mathrm{kg} \cdot \mathrm{cm}^{-2}$.

In the next step, it was decided to make a valve seat at the bottom with channels feeding the medium to the actuator chamber. This means a significant increase in the size of the bottom (and thus an increase in its safety factor). Additional construction details:

- ducts feeding the actuator chamber into the working medium, their dimensions depend mainly on the type of actuator housing (connection dimensions, pressure). Very important for the final bottom dimension is the length of the used thread;

- Archimedes spiral, the task of this solution is to facilitate the piston detachment from the bottom at moving;

- cylindrical silencer, its function is to suppress the piston and prevent it from hitting the bottom (this can lead to damage to the actuator). The slot dimensions can be calculated, but it is also possible to select them in an experimental way. 


\section{Piston and piston rod}

Piston rods are usually made of thermally improved, alloyed or carbon steel. The end of the piston rod is usually equipped with a suitable end for later mounting to the devices driven by the actuator. For example, articulated eyes, threaded endings, etc. may be used. The piston rod surface should be very smooth and protected against the influence of external environment by means of a layer, e.g. chromium. Selection of protecting substance is closely related to operating conditions of the device. In industrial practice, chromium and antykollayers are used (oil resistant to aggressive salt environments). The piston rod of the actuator is calculated due to its ability to buckle the effect of force in its axis. The diameter of the piston rod was selected experimentally for both briquetting presses and is $\emptyset 120 \mathrm{~mm}$. While the piston rod length results directly from the required piston stroke and machine dimensions.

Pistons are usually made of cast iron, bronze, steel or coated steel with a bronze layer. The piston dimensions are closely related to the internal dimensions of the actuator cylinder and external piston rod. In addition, selection of appropriate seals has a very significant impact on the external geometry. When $\mathrm{U}$ or $\mathrm{V}$ type seals are used, the leading part of the piston must be made with f8 tolerance. These seals should be used in pairs, as each of them works only in one direction [16]. Detailed design solutions:

- $\quad$ piston and cylinder sealing groove - due to frequent pressure strokes, the GER type seal was selected;

- leading belts grooves - this is a direct consequence of the use of GER type seal;

- piston rod and piston sealing groove, a classic O-ring was used to ensure minimal losses due to internal leakage between chambers;

- mounting holes - four holes are drilled to facilitate the assembly of the piston, which makes it easier to achieve the correct tightening torque;

- final dimension of the piston also depends on the required thread length, by means of which it is fastened to the piston rod.

\section{Computational model of the piston}

Piston is solid of revolution symmetrical relative to two plains. This simplifies the model considerably. Instead of the entire piston, only its fragment is sufficient, a quarter of the total. Such a solution enables to save a lot of time on calculations. In such a situation it is necessary to apply the symmetry conditions of the model. This consists in blocking the ability to move the solid in a direction perpendicular to the plane of symmetry. The model has been "established" in such a way as to best reflect the real connection conditions of the piston with the piston rod (Figure 3).

Places where the stresses accumulate are the back wall and hole on the element forehead. The maximum appointed stresses (according to FEM analysis, Figure 4) shall not exceed $200 \mathrm{MPa}$. This means that the piston is completely safe during pressing.

Further structural calculations were related to:

- gland (actuator covers);

- flange attached to the cylinder by means of two fillet and end welds, and threaded connection, as well as selection of the flange thicknesses;

- calculation of bolt dimensions to be used, when attaching the actuator to the body;

- press body, which connects the main actuator with the support plate and other press parts (their task is to carry the loads connected with the cylinder operation and serve as a fixing point for some elements);

- FEM analysis to verify the maximum stress for the actuator during pressing and stroke return;

- FEM analysis to verify the maximum stresses for the body (reduction of the ejector hole size);

- fatigue calculations for the body (Wöhler's fatigue strength curve for 18G2A steel has been used, and for the forces corresponding to 600 and $700 \mathrm{kN}$, the body has reached the unlimited fatigue strength range). 


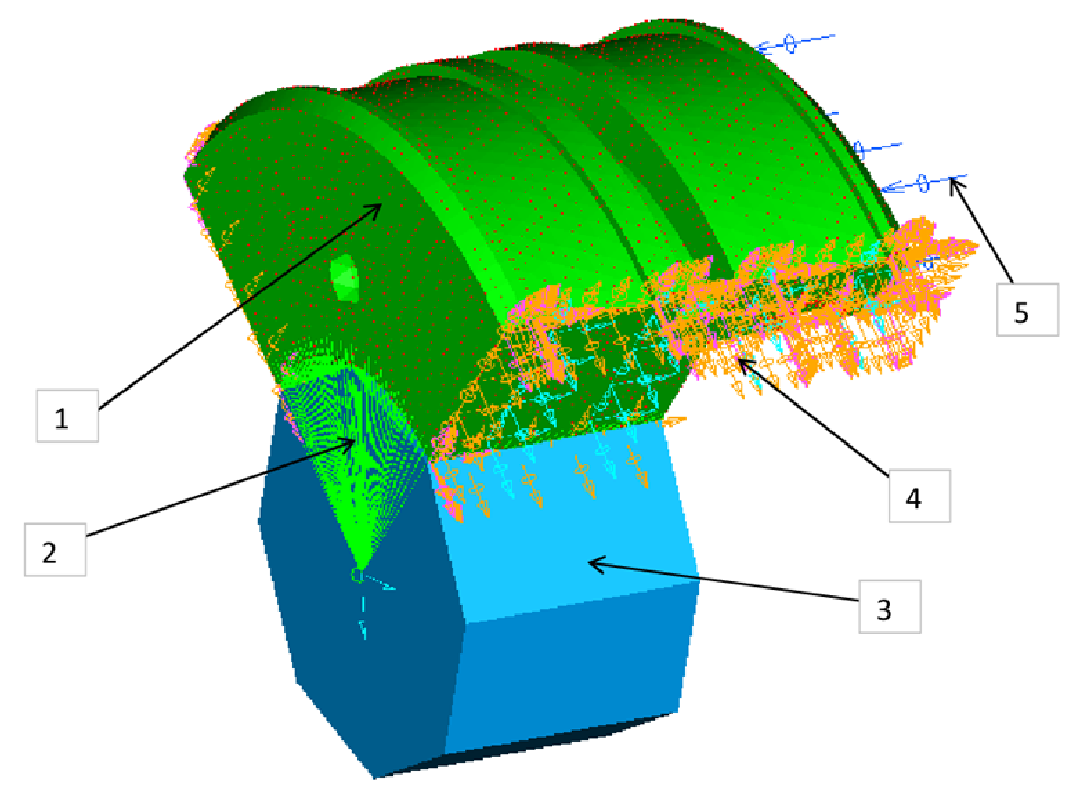

Fig. 3. Computational model of piston: 1 - piston was covered with a grid of spatial elements of Tetra 10 type with dimension 3;2 -maintenance of thread was simulated with the use of susceptible elements of Constrain type; 3 -beam elements were used to form the piston rod section, the model was fixed at the end of piston rod nodes; 4 - symmetry conditions; 5 - pressure loads, two cases were taken into account: during pressing and when the piston returns

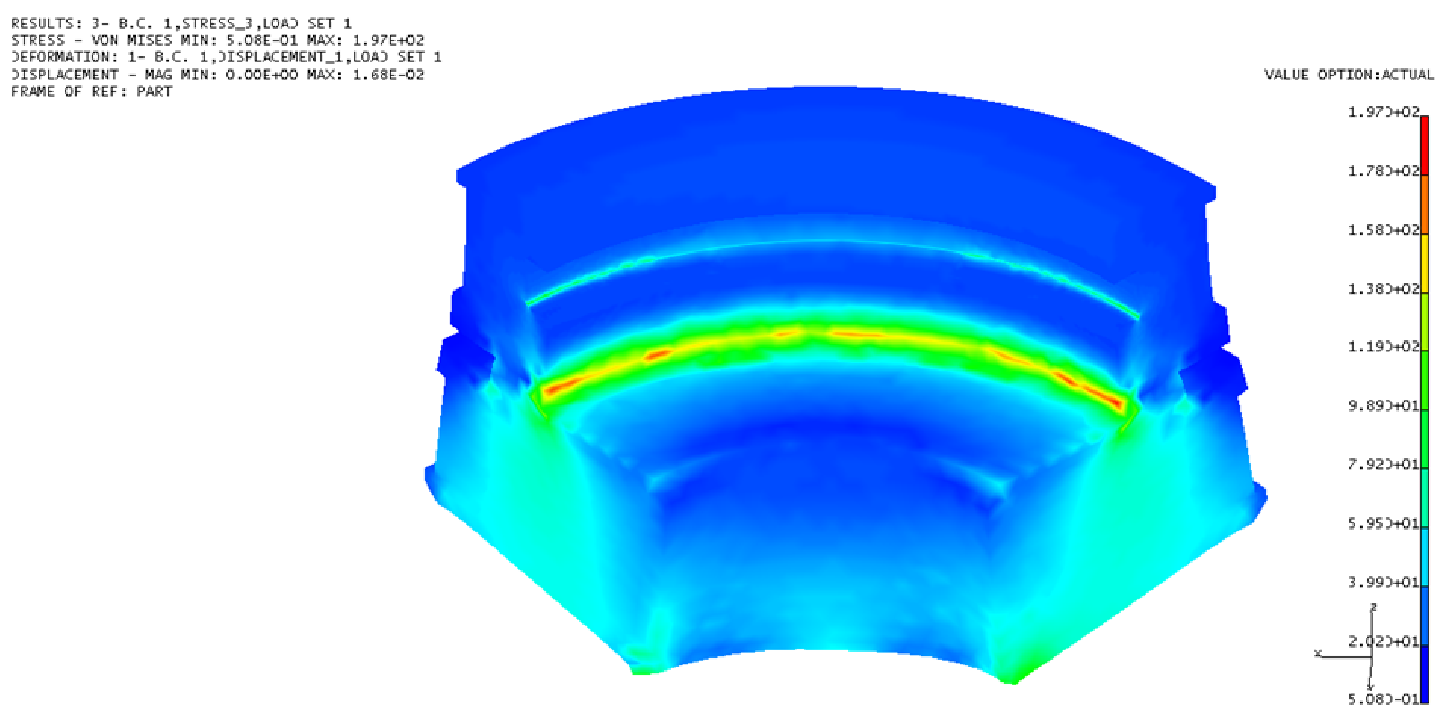

Fig. 4. Model calculation results of piston for load while pressing

\section{Results and discussion: Technological process and discrete simulation of the production process}

Technological processes were developed and machining technology was selected for the designed actuator parts to the briquetting press. Subsequently, it was necessary to determine surcharges for specific semi-finished products. As a part of technological processes development, tools for processing in individual operations were selected on the basis of available catalogues. Available machines and equipment have been assigned for implementation of individual technological operations:

- cutting on a band saw;

- processing of front surfaces on a universal lathe, CNC lathe and vertical drilling machine;

- processing of exterior surfaces on a universal lathe, CNC lathe, universal milling machine and CNC milling machine, as well as milling machine;

- processing of inner surface on a universal lathe, $\mathrm{CNC}$ lathe and $\mathrm{CNC}$ milling machine; 
- welding on manual and automatic welding station;

- sub-assemblies and final assembly.

Working time standardization is another stage in the design of technological processes. The working time standard is technically a justifiable amount of time necessary to perform a certain range of work under the given technical and organisational conditions of the plant, by a certain number of qualified contractors [17]. Different methods of analysis of mechanical processing times are used depending on the production volume:

- analytical method is very well suited for serial and large-scale production;

- experimental method is used for production of unit or very small batches, as a comparison with already carried out works.

Management of the manufacturing process, in particular in unit production, is faced with the problem of constantly directing people to tasks, assigning work adapted to their current production possibilities, thus creating the conditions for ensuring the product quality [18; 19].

The production series of the actuator to the briquetting press will be 5 pcs. This is undoubtedly a unitary production, while the selection of technological operation times was based on the technological experience. Simulation model was based on the location of the company's workstations, in which it was planned to start the production of briquetting work, presented in Figure 5.

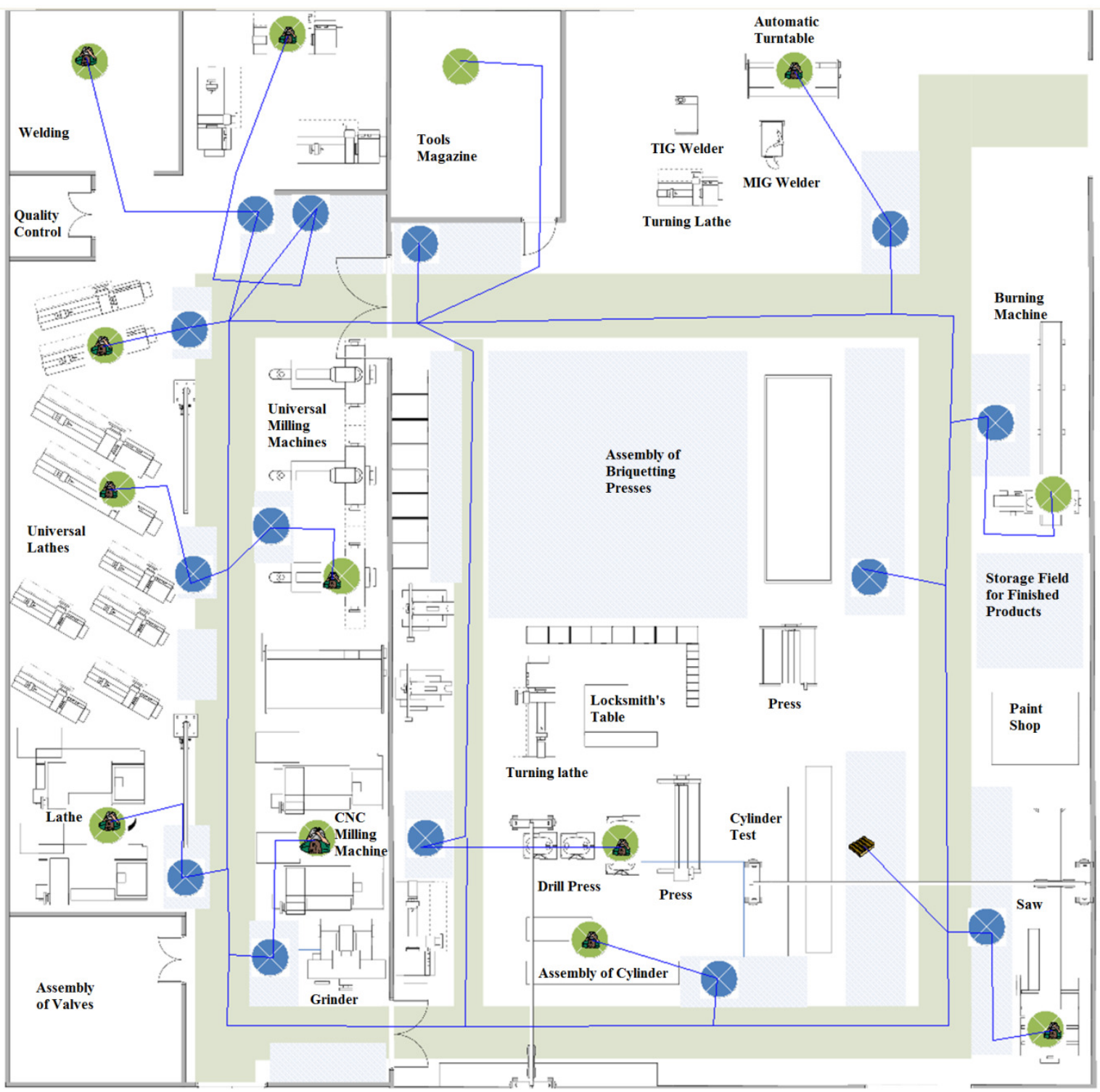

Fig. 5. Layout of workstations in simulation model of production process 
The following preliminary assumptions were used in the simulation model:

- simulation involves processing and assembly of all seven actuator elements;

- actuator production batch is five pieces;

- all raw materials are taken from the stock of raw materials;

- internal transport is handled by operators;

- each machine has a buffer;

- actuator is sealed by means of components taken from the warehouse;

- assembly operations are also carried out on welding stations;

- each machine is operated by one operator, except for a band saw and machine tool, which are operated by two operators.

\section{Simulation results}

A very important issue, in order to facilitate production scheduling, is the time counted in manhours, after which a series of five actuators is ready for assembly. It was recorded after simulation tests of the production system (Figure 6). The value 0 means that there are no actuators in the press assembly station, the value 1 means: the element is in the assembly stand, ready for assembly.

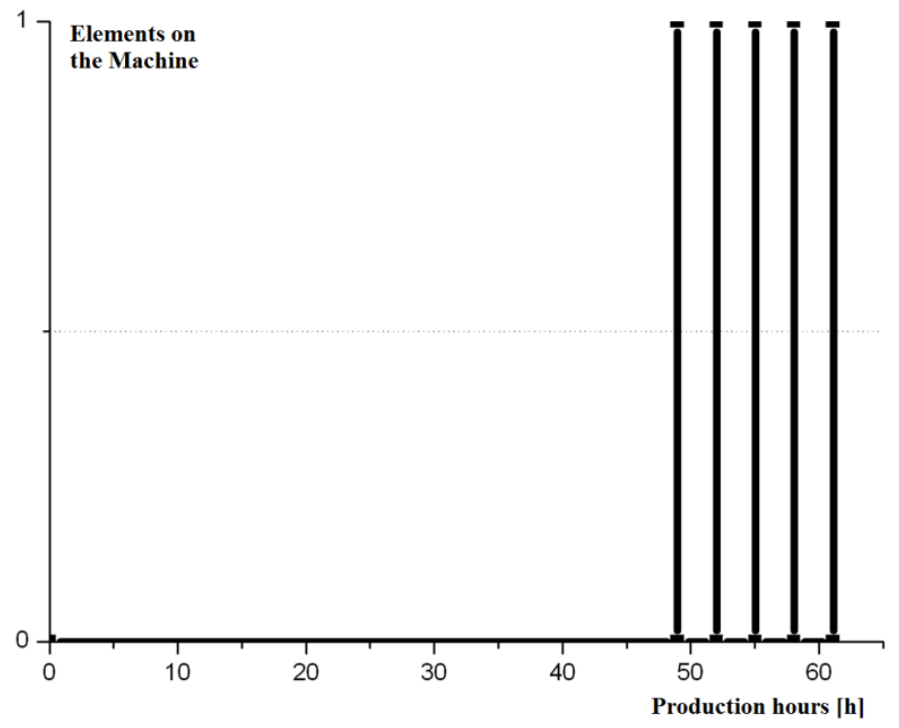

Fig. 6. Delivery times of actuators to press assembly position station

Another important issue is the load on machine tools and workers; this load indicated from the results of simulation tests does not exceed $65 \%$. This is a standard result for unit production, with the load set at a much lower level for most machines [20]. Therefore, machine load is highly uneven, which is another characteristic of unit production.

\section{Conclusions}

During the design process of the briquetting press, the following pointers and conclusions were collected, which can be used for further development of product variants:

- the best briquette is produced using the maximum operating pressure in the actuator;

- maximum operating pressures occur during pressing and stroke return ( 30 MPa), the working pressure value is a key parameter for further calculations;

- using formula 2 to calculate the cylinder wall thickness is associated with a large error in the strength calculations of the actuator;

- suggested connection between the bottom and cylinder is a threaded and welded connection;

- analysis of key structural elements with FEM to verify maximum stresses proved to be crucial for the safety of briquetting operation;

- the hydraulic cylinder of the press for analysed load is within a safe stress range; 
- reducing the size of the ejector hole, the notch size is increased, which increases the stress values on less beneficial;

- the body loaded with a tensile force of 700 and $600 \mathrm{kN}$ is a completely safe solution in the analysed case;

- fatigue analysis of the body showed that for 900,850 and $800 \mathrm{kN}$ loads the maximum number of cycles for damage is about 150000,220000 and 375000 , for 700 and $600 \mathrm{kN}$ forces the body is within the range of unlimited fatigue strength.

After confirming the correctness of the applied solutions and assigning the actuator for production, it is possible to proceed to technological part of the project. Conclusions for the technological part:

- thanks to providing the best quality of construction works, the actuator parts are characterized by a high degree of technological level, which allowed easily to select materials, required machines and arrange the processing technology;

- for the manufacture of actuator parts, only typical tools from the available catalogues are used;

- only standard machines and technological equipment such as lathes, as well as universal and CNC milling machines, vertical drills, band saws, milling machines and welding stations (automatic and manual) will be used for the production process;

- time of individual operations was selected on the basis of experience in unit production;

- after the design of the technological process, it is possible to carry out simulation tests of actuator production, thanks to the simulation model it is possible to determine the time of actuator production batch for the existing layout;

- low load capacity of the machines and operators is expected as a result of start-up of the production process and its unit nature.

Even before the first batch of five presses was launched, the company decided to produce a complete prototype for further analytical work and to issue the manufacturer's declaration of conformity of the machine design with the EU directives and relevant PN-EN standards.

\section{References}

[1] Grzybowska K., Gajdzik B. Optymisation of equipment setup processes in enterprises. Metalurgija,vol. 51 (4), 2012, pp. 555-558.

[2] Saniuk A., Jasiulewicz-Kaczmarek M., Samolejová A., Saniuk S., Lenort R. Environmental favourable foundries through maintenance activities. Metalurgija vol. 54 (4), 2015, pp. 725-728.

[3] Kłosowski G., Kozłowski E., Gola A. Integer Linear Programming in Optimization of Waste After Cutting in the Furniture Manufacturing.Proceedings of International Conference "Intelligent Systems in Production Engineering and Maintenance", 2017, Wrocław, Poland, pp. 260-270, DOI:https://doi.org/10.1007/978-3-319-64465-3_26

[4] Passetti E., Tenucci A. Eco-efficiency measurement and the influence of organisational factors: evidence from large Italian companies. Journal of Cleaner Production, vol. 122, 2016, pp. 228239. DOI: https://doi.org/10.1016/j.jclepro.2016.02.035

[5] Simon L., Moraes C., Modolo R., Vargas M., Calheiro D., Brehm F. Recycling of contaminated metallic chip based on eco-efficiency and eco-effectiveness approaches. Journal of Cleaner Production, vol. 153, 2017, pp. 417-424. DOI:https://doi.org/10.1016/j.jclepro.2016.11.058

[6] Sverdrup H., Ragnarsdottir K., Koca D. 2017. An assessment of metal supply sustainability as an input to policy: security of supply extraction rates, stocks-in-use, recycling, and risk of scarcity. Journal of Cleaner Production,vol. 140, 2017, pp. 359-372.

DOI: https://doi.org/10.1016/j.jclepro.2015.06.085

[7] Lela B., Barišić M., Nižetić S. Cardboard/sawdust briquettes as biomass fuel: Physicalmechanical and thermal characteristics. Waste Management,vol. 47, 2016, pp. 236-245. DOI:https://doi.org/10.1016/j.wasman.2015.10.035

[8] Shuma R., Madyira D. Production of Loose Biomass Briquettes from Agricultural and Forestry Residues. Procedia Manufacturing, vol. 7, 2017, pp. 98-105.

DOI: https://doi.org/10.1016/j.promfg.2016.12.026 
[9] Stolarski M., Krzyżaniak M., Warmiński K., Niksa D. Energy consumption and costs of heating a detached house with wood briquettes in comparison to other fuels. Energy Conversion and Management,vol. 121, 2016, pp. 71-83. DOI: https://doi.org/10.1016/j.enconman.2016.05.031

[10] Stolarski M., Szczukowski S., Tworkowski J., Krzyżaniak M., Gulczyński P., Mleczek M. Comparison of quality and production cost of briquettes made from agricultural and forest origin biomass. Renewable Energy, vol. 57, 2013, pp. 20-26. DOI:https://doi.org/10.1016/j.renene.2013.01.005

[11]Talaśka K. Analysis of the Energy Efficiency of the Shredded Wood Material Densification Process. Procedia Engineering, vol. 177, 2017, pp. 352-357.

DOI:https://doi.org/10.1016/j.proeng.2017.02.205

[12] Križan P., Matúš M., Šooš L. Design of Pressing Chamber of Briquetting Machine with Horizontal Pressing Axis. Proceedings of International Conference "Advanced Production Technologies", 2012, Novi Sad, Serbia, pp. 361-364.

[13]Repsa E., Kronbergs E., Smits M. Evaluation of Biomass Compacting Mechanisms. In Proceedings of International Conference "Renewable energy and energy efficiency", 2012, Jelgava, Latvia, pp. 179-184.

[14] PN-72/M-73202. "Napęd i sterowanie hydrauliczne. Cylindry (siłowniki) hydrauliczne. Ogólne wymagania i badania" (Drive and hydraulic control. Hydraulic cylinders (actuators). General requirements and tests). (In Polish).

[15] Marutow W. A., Pawłowskij S. A. Cylindry Hydrauliczne. Konstrukcja i obliczanie (Hydraulic Cylinders. Construction and calculation). Wydawnictwo Naukowo-Techniczne, 1968, Warszawa, Poland, (In Polish).

[16] Szydlewski Z., Olechowicz J. Elementy napędu i sterowania hydraulicznego i pneumatycznego (Elements of hydraulic and pneumatic drive and control). Państwowe Wydawnictwo Naukowe, 1986, Warszawa, Poland, 134 p. (In Polish).

[17] Jasiński Z. Organizacja przebiegu pracy w systemie produkcyjnym (Organization of the workflow in the production system). Proceedings of conference "Innowacje w Zarządzaniu i Inżynierii Produkcji”, 2013, Zakopane, Poland, pp. 457-460. (In Polish).

[18] Feld M. Podstawy projektowania procesów technologicznych typowych części maszyn (The basics of designing technological processes of typical machine parts). Four edition. Wydawnictwa Naukowo-Techniczne, 2009, Warszawa, Poland, 708 p. (In Polish).

[19] Jasiulewicz-Kaczmarek M., Saniuk A. How to Make Maintenance Processes More Efficient Using Lean Tools? Proceedings of International Conference "Advances in Social \& Occupational Ergonomics”, 2017, Los Angeles, USA, pp. 9-20, DOI:https://doi.org/10.1007/978-3-319-60828-0_2

[20] Kowalski A., Marut T. 2012. Hybrid methods aiding organisational and technological production preparation using simulation models of nonlinear production systems. Proceedings of International Conference "Hybrid Artificial Intelligence Systems",2012, Salamanca, Spain, pp. 259-266. 